\author{
Yuriy Prudnikov, \\ Ph.D. in Medicine, \\ Institute for International Cooperation Development, Poland \\ email: prudnikovdonetck@gmail.com \\ (iD) ORCID ID, 0000-0003-2455-9872 \\ Anastasiya Nazarenko, \\ Sumy State University, Ukraine \\ email: anastasian123001@gmail.com
}

\title{
THE ROLE OF CONTENT MARKETING IN THE PROMOTION OF MEDICAL GOODS AND SERVICES
}

\begin{abstract}
The main purpose of the research is highlighting the role of quality medical content marketing, the main problems that arise in the implementation of content strategies on the example of modern Sumy medical institutions, providing recommendations for its improvement. Systematization literary sources and approaches for solving the problem indicates that the search for new marketing tools to inform and stimulate the purchase of customers about medical goods and services (passive demand) in the online sphere remains a very relevant topic. This is evidenced by the search for modern trends in the use of marketing in medicine, a comprehensive study of marketing technologies for managing activities in the health care system. At the same time, content marketing is considered as a tool for indirectly persuading the audience to make the decision necessary for the distributor, to choose his service. Investigation of the topic research on the role of marketing content in the promotion of medical goods and services in the paper is carried out in the following logical sequence: description of the benefits of using content marketing, the importance of compliance with legal requirements when advertising and filling sites and pages on social networks, presenting the results of content analysis of selected clinics, development of proposals to improve their content strategies. Methodological tools of the research methods included systematization of information based on the content analysis of official sites, social networks of selected medical institutions. The object of research is the chosen medical companies (public and private medical centers, dental clinics and medical pharmaceutical institutions), because namely they they are the most visited in the city, have a high level of competition, which means they should be interested in online promotion of services (especially during a pandemic). The research theoretically proves that content marketing is today an integral part of the promotion of medical institutions in the network, reveals the problem of insufficient understanding in the correct use of this tool by Sumy clinics.
\end{abstract}

Key words: clinics, medical centers, reviews, social networks, Unique Selling Point.

Introduction. In recent years, the growing relevance of the concept of medical marketing in the field of promotion of medical services can be observed. This is due to both the specifics of the medical industry and the peculiarities of the relationship between health care providers and their consumers.

The American Marketing Association has defined in detail the concept of medical marketing as an integrated process of planning, economic justification, and management of medical services, pricing in the field of treatment and prevention, promotion of services (medical products), and their implementation (Makhnusha and Shevchenko, 2013). A successful medical marketing strategy includes improving the brand of the clinic, the use of technological solutions, maintaining the impeccable reputation of doctors. But the most important thing is the proper use of content marketing.

Content marketing is a collection of marketing techniques that are used to create and disseminate useful information, including advertisements, to customers. Free and high-quality content creates added value for customers. This approach to selling with the content marketing toolkit encourages people to buy

Cite as: Prudnikov, Yu., \& Nazarenko, A. (2021). The Role of Content Marketing in the Promotion of Medical Goods and Services. Health Economics and Management Review, 1, 23-29. http://doi.org/10.21272/hem.2021.1-02 
more by engaging them in the company's social media space. That is why many large medical companies see content marketing as the main way to attract customers.

Literature Review. Scientific researches related to the field of health care and marketing of medical services were traced in the works of both domestic and foreign scientists: Antosova et al. (2020), Khomenko et al. (2020), Ovsyanetska (2012), Taran (2020), Pishchikov et al.(2015), Bilak and Bora (2017), Baeva (2008), Rosokhata et al. (2020), Teletov et al. (2019) and others.

Regarding research specifically on content marketing as the main way of development of Internet marketing of medical services, among the thematic publications we can highlight the works of Constantinescu-Dobra (2014), Elmortada et al. (2020), Thorikov (2016), Sokolova and Pasichnyk (2019), Shelushko (2019), Costa (2014) etc.

However, issues related to the content marketing of medical services in Sumy and Ukraine in general, still remain open for further research, which determines the relevance of the chosen topic.

Methodology and research methods. To study the importance of content marketing for medical institutions, scientific articles and electronic resources were analyzed and compared in pairs to identify current trends.

The article analyzes the official sites and pages on social networks of the most visited and popular medical institutions (state medical centers, dental clinics, pharmaceuticals, medical institutions). According to the content analysis results, separate lists were formed with characteristic features - both disadvantages and advantages of the existing use of content marketing. As a result, problems of insufficient involvement (especially of dental clinics) in the social network were revealed and the most frequent lack of regularity in the publication of posts and processing of feedback. To obtain information on attracting and processing customer feedback, the ranking of clinics in the Google search engine was analyzed separately, which allowed obtaining the most up-to-date data.

In general, the study is based on the principle of inductive analysis of objects, which allowed to draw appropriate conclusions and provide recommendations.

Results. Content marketing is defined as strategic marketing and business process focused on creating and disseminating valuable, relevant, and consistent content to attract and retain a clearly defined audience and, ultimately, stimulation of the profitable activity of the customer (HubSpot Academy, n.d.). In other words, in the medical field, content marketing is an important long-term strategy that involves creating interesting, useful, informative, and educational content for the healthcare marketing audience.

Although content marketing is not intended to promote a brand, product, or service, many benefits and advantages justify its investment:

- availability of useful and interesting content for the user. Healthcare leadership is usually made up of people who are eager for authoritative details about a subject or topic related to health or a service/procedure that interests them. Readers may be potential customers or possibly their friends/family members;

- expanding the audience through the exchange of information. As a reliable resource, relevant online information will be disseminated among readers, and some materials will be in greater demand than others;

- improving brand awareness and trust. High-quality content allows the brand to be noticed and evaluated, provides an opportunity to regularly demonstrate their knowledge and experience in this area;

- stimulating brand loyalty. The reputation of an expert, a leader in this field encourages customers to return in the future. Building trust and customer experience are closely linked;

- increasing the number of subscribers in social networks. Digital content is often intended for use in several forms or formats. For example, content blogs/articles are usually promoted through social platforms; 
- search engine optimization (SEO). Regular publication of new and expert information, which uses relevant keywords in the text, title, summary, and other places of the content contributes to the visibility and ranking of search results and more. In other words, in the medical field, content marketing is an important long-term strategy that involves creating interesting, useful, informative and educational content for the healthcare marketing audience.

To achieve the goals of content marketing and achieve the above benefits, there are many tools:

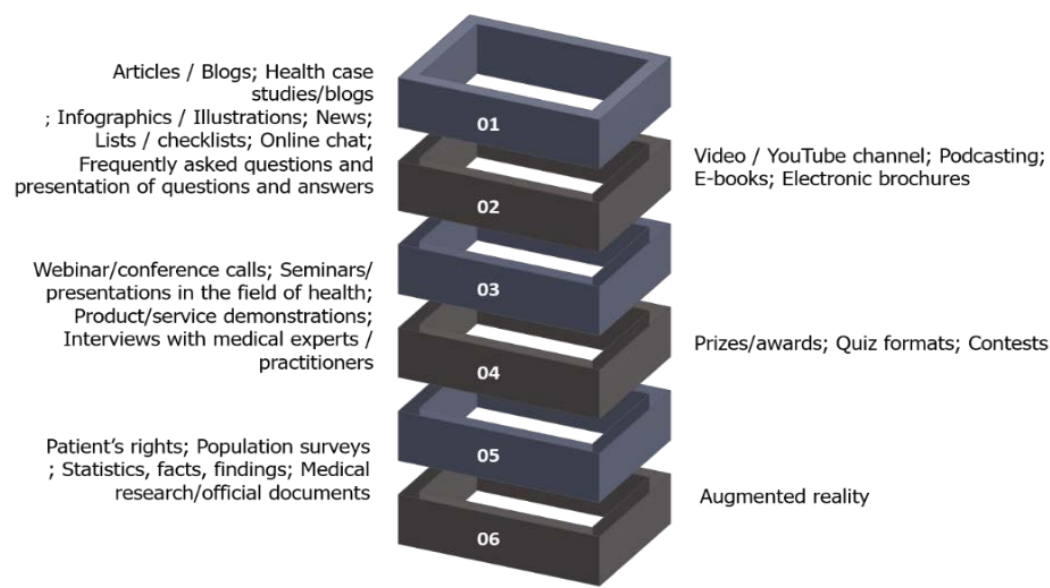

Figure 1. The most common methods of content marketing

Sources: developed by the authors.

Practitioners and organizations need content marketing to get their message across to the audience. Effective communication is essential for a successful doctor-patient relationship, especially when discussing cancer, obesity, sexual dysfunction, and other sensitive topics. Poor communication can cause doubts, false hopes and unrealistic expectations about the results of treatment.

As a rule, patients are poorly informed about the services provided, they cannot determine the quality of medical services, but only evaluate the services provided and are therefore forced to trust the specialist. The level of trust in the doctor and the clinic can simplify or complicate the treatment process. In the latter case, hints at the phenomenon of iatrogenic diseases - psychological disorders that occur as a result of deontological errors of health professionals - incorrect, careless statements or actions (Hrytchuk et al., 2004).

Doctors and other health professionals may not fully appreciate the nuances of compliance with the Law of Ukraine «On Advertising» and other regulatory requirements applied by government agencies, so they need content marketers who understand this.

There is a fine line between acceptable medical marketing methods and unacceptable ones. While many people use the Internet to diagnose and treat disease, professional medical marketers know that Ukrainian law requires people to be warned about the dangers of self-medication, the need to consult a doctor and read the instructions.

It is forbidden to use several techniques to which marketers from other fields are accustomed:

- safety and reliability. There is no guarantee that the tool will work, to declare the absence of side effects. It is also not possible to argue for the benefits of natural origin or mandatory registration tests; The law requires that clinic advertisements do not give the impression that people should use medical services. You can not push people to self-diagnosis, to assume that the audience has a disease. It is also forbidden 
to depict changes that occur in the body due to disease and threaten to worsen if a person does not use the advertised product;

- halo effect. Mention of experts, stars, famous organizations, and popular characters, showing the actor as a doctor in medical advertising is prohibited;

- cases, reviews. In Ukraine, any reference to examples of successful treatment is prohibited (for example, the story of how friendly the patient became after teeth whitening and how it helped him in life).

The consequences of such violations are the imposition of fines (sometimes in the amount of $5-10 \%$ of annual income), criminal liability. Thus, in February 2019, the laser cosmetology center «Laserhouse» in Sumy was fined for placing outdoor advertising without permission, lack of text warning «Self-medication can be harmful to your health» (RegioNews-Sumy, 2019).

In general, there are separate content marketing strategies for each type of medical institution, but there are some general criteria:

- $\quad$ the clinic must have a UTP (unique trade offer). That is, what distinguishes it among the like;

- there must be a certain product line that allows you to guide the patient at all stages of treatment without losing it, and allows you to earn and plan admissions;

- $\quad$ the clinic must be integral (logo, range of services, representation in media channels).

State medical centers. The public sector in any field of activity has some advantages: administrative resources, preferential prices for suppliers, opportunities for lobbying, etc. In the field of health care, public clinics can take advantage of these benefits to at least maintain a customer base. The big medical business invests both in the purchase of new equipment and technologies and in raising the professional level of specialists. But it is impossible to develop and go further on their own without a marketing-oriented strategy of the state in the field of medicine. This is a significant disadvantage, in contrast to the existing advantages. In addition, district clinics are often associated with the minds of people with certain difficulties (Fig. 2).

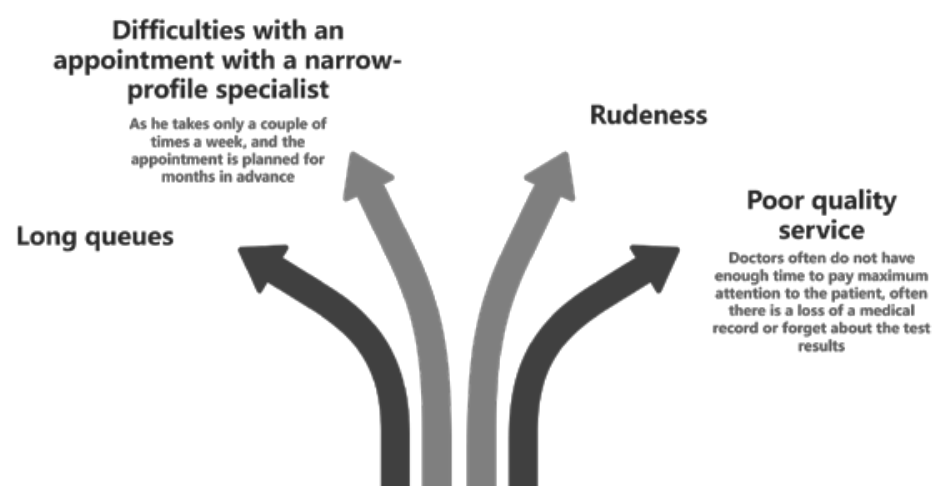

Figure 2. Common problems of public clinics

Sources: developed by the authors.

There are about 53 state hospitals and clinics in Sumy. Of these, the applied content of the top 20 government agencies was analyzed and identified the main characteristics and errors: Facebook;

- most hospitals have official websites, pages are maintained mainly on the social network

- $\quad$ posts on social networks are published either irregularly or too often (4-5 posts per day);

- $\quad$ chatbots are inserted in the social network Facebook; 
- lack of maintaining a single style of communication with the audience;

- $\quad$ no competitive advantage (UTP);

- no advertising on social networks and contextual advertising;

- not processed feedback (both positive and negative from customers).

Therefore, concerning content marketing in Sumy state medical institutions, certain shortcomings have identified that need to be corrected accordingly, but what distinguishes these institutions from others - the decisive factor is still management - depends on the progressiveness of the head its condition, relationship with the client and the presence of specialists.

Also, medical management means one of the modern areas of management. His tasks include general management, control over financial flows, and solving current problems in the field of health care.

Private medical clinics. The developed infrastructure of public medicine and its image as more accessible to the public, of course, attractive in terms of marketing, but private medicine successfully fights for its customers, attracting their transparency and clarity of financial relationships, comfort, service, and quality of services, patient protection.

The main feature of a private medical center is that its main task is to increase profits. In this case, the patient is at the center of attention and should receive professional and prompt high-quality medical care.

Based on this, 25 private medical clinics were analyzed, including centers of aesthetic cosmetology. The general features of content marketing include:

- active activity in social networks Facebook, Instagram, the presence of an official site is a mandatory factor;

- the presence of SMM-strategy (acquaintance with clinic doctors, news and articles) with expert opinions, entertaining content - rubric «truth or myth», chatbots, infographics);

- chaotic publication of posts;

- mostly the absence of UTP (template behavior);

- video content is rarely used (channels on Youtube);

- patient satisfaction is not assessed;

- lack of advertising in search engines and social networks.

Despite the relative «advanced» content marketing of private organizations compared to public institutions, they have some common mistakes. It is extremely important to encourage satisfied customers to give feedback and process negative feedback. This will help increase the trust of existing and potential customers. Promotion of the clinic is also possible through the Youtube channel. Video content is becoming more and more relevant, users' attention can be drawn to information related to:

- life of leading doctors of the clinic, their career;

- profile humor;

- reports on participation in various events;

- online conferences, seminars, broadcasts (telemarketing is becoming very popular);

- competitions;

- interviews with specialists of a narrow profile.

These recommendations are aimed at establishing communication with clients, as well as increasing brand loyalty to a private clinic, ensuring its transparency.

Dental clinics. Dentistry was singled out - it is considered a major pioneer in medical marketing in the post-Soviet space, as these services are not directly related to saving lives, so in the mass consciousness they can be perceived as «frivolous» and therefore suitable for advertising.

Unfortunately, in Sumy, despite the high level of competition, online promotion of dental clinics, both private and public, has not yet become widespread. This is evidenced by the results of the content analysis of the 20 most popular dental clinics in the region: 
- most do not have official sites or outdated information sites;

- most pages on social networks Facebook and Instagram have ceased activity (the last posts date 2020 year) or absent, chaotic publication of posts;

- UTP is announced (often as the main goal of the clinic);

- $\quad$ negative feedback is processed.

Today, dental clinics should not rely solely on sundresses radio. Supply has long exceeded demand, so a method of distinguishing between competitors should be used. In addition to setting up content strategies, Sumy dental clinics need to start with the basic aspects - creating official websites (updating the information available on them), setting up business pages on social networks (the most common are Facebook and Instagram). As content, we recommend publications with photos «before-after», articles with expert opinions, acquaintances with doctors, video content, the use of email marketing.

Medical pharmaceutical institutions. The promotion of pharmacies on the Internet today has become especially relevant. The global pandemic has generated increased demand for pharmaceuticals. And even significantly increased the demand for some items (antiseptics, antipyretics, painkillers). There is also a separate large area of pharmaceutical marketing from a broad perspective on the entire field of production of drugs and services, as well as their implementation.

It should be borne in mind that here the role of buyers are patients, each of whom has their own needs for medicines. The emergence of a wide range of drugs creates high competition among manufacturers. Pharmaceutical content marketing can influence which drug the consumer chooses as a result.

There are about 102 pharmacies in Sumy. The content of 7 main pharmacy chains in the region was analyzed (among them pharmacies «We wish health», «ANC», «Berehynia», «Plantain», etc.):

- most pharmacies have official websites;

- only 3 pharmacies from the analyzed ones are working on negative reviews, attracting suggestions for improving the service on the sites;

- email marketing is used;

- $\quad$ some pharmacies are not registered in social networks (or have stopped posting);

- $\quad$ posts are often published exclusively with promotional offers.

One of the important problems is that the format of online booking of medicines is not very fast and not convenient enough in terms of user experience. So there is an opportunity to refine the functionality directly to e-commerce: the convenience of the site and booking or buying online.

Conclusions. Content marketing is natural for many hospitals and health care providers. It is a way to effectively communicate with people and provide them with useful and interesting information. Among the benefits, it is a marketing tool for attracting patients, retaining, branding and enhancing professional reputation. Its owners are increasingly delving into the online promotion of clinics, pharmacies, hospitals, etc. (given the transition to an online environment globally). But a very important link, which is still not taken into account, is the use of content. Medicine is based on the patient's trust in the doctor, so the mere fact of registering a business on social networks is not enough, it is important to fill websites, pages with timely, relevant and useful information for consumers, thus ensuring transparency and brand loyalty.

At the global level, the problems that arise in Sumy medical institutions with content marketing and medical marketing in general are due to the lack of specialists in this market in sufficient numbers, because medical marketers are not trained anywhere, and real talented professionals, unfortunately, not enough. Another factor is directly related to the mentality of the population - the high frequency of self-medication, which reduces the effectiveness of treatment. In this case, the state's efforts should be aimed at supporting educational institutions and educational programs for the training of medical marketing specialists, the development of marketing consulting programs for medical institutions, creating a positive image of the doctor, medical institution and health care in general. 


\section{References}

Antosova, I., Hazuchova, N., Stakova, J. (2019). Market Segmentation in Healthcare. Marketing and Management of Innovations, 3, 151-166. http://doi.org/10.21272/mmi.2019.3-12 [Link]

Constantinescu-Dobra, A. (2014) Content Marketing in Dentist's Websites. An Empirical Comparative Study between Romania and the UK. In: Vlad S., Ciupa R. (eds) International Conference on Advancements of Medicine and Health Care through Technology; 5th - 7th June 2014, Cluj-Napoca, Romania. IFMBE Proceedings, vol 44. Springer, Cham. https://doi.org/10.1007/978-3-319-076539_22 [Link]

Costa, T. F. T. (2014). Pharmaceutical marketing and social media: a facebook, twitter and youtube analysis (Doctoral dissertation). [Google Scholar]

Elmortada, A., Mokhlis, C.-E., Mokhlis, A. \& Elfezazi, S. (2020). Innovations in HR Management: a Content Analysis Approach. Marketing and Management of Innovations, 1, 182-191. http://doi.org/10.21272/mmi.2020.1-14 [Link]

Hospitals and clinics of Sumy. Retrieved from [Link]

Hrytchuk, Ya. S., Pavlychko, Yu. M., \& Hrytchuk, Ya. M. (2004). The role of a doctor in the iatrogenic diseases occurrence. Medicine of railway transport of Ukraine, 2., 98-99. Retrieved from [Link]

HubSpot Academy (n.d.). Content Marketing Workbook A Beginner's Guide to Applying Content Marketing to Your Business (3rd ed). Retrieved from [Link]

Khomenko, L., Saher, L., Polcyn, J. (2020). Analysis of the Marketing Activities in the Blood Service: Bibliometric Analysis. Health Economics and Management Review, 1, 20-36. DOI: 10.21272/hem.2020.1-02 [Link]

Makhnusha, S. M., \& Shevchenko, O. Yu. (2013). Marketing system of health care in modern socio-economic conditions. Retrieved from [Link]

RegioNews-Sumy. (2019). Laserhouse in Sumy fined for violating the law on advertising. Retrieved from [Link]

Rosokhata, A., Letunovska N., Jasnikowski, A., \& Moiseienko, D. (2020) Marketing services mix for healthy territories: Europe Ukraine features. Economic space, 147(2), 13-19 [Link]

Shelusko, D. V. (2018). Internet marketing and smm in promotion of medical companies. In Interdisciplinary Research: New Formats and Directions in a Multiethnic Educational Space (pp. 63-67). Retrieved from [Link]

Sokolova, Yu. O., \& Pasichnyk, K. V. (2019). Improving the activities of the state medical institution on the basis of marketing. Market infrastructure, 37. Retrieved from [Link]

Teletov, A., Letunovska, N., \& Melnyk, Yu. (2019). Four-vector efficiency of infrastructure in the system of providing regional socially significant needs taking into account the concept of marketing of changes. Bioscience Biotechnology Research Communications, 12(3), 637-645 http://dx.doi.org/10.21786/bbrc/12.3/13 [Link]

Tkhorikov, B. A. (2016). Content manager of the state medical organization. In human resources management in the modern world: trends and challenges of the 21st century (pp. 66-70). Retrieved from [Link]

Юрій Прудніков, канд. мед. наук, lнститут розвитку міжнародної співпраці (Польща);

Анастасія Назаренко, Сумський державний університет (Україна)

Роль контент-маркетингу у просуванні медичних товарів і послуг

Основною метою дослідження $є$ висвітлення ролі маркетингу медичного контенту, основних проблем, що виникають при реалізації контент-стратегій на прикладі сучасних сумських медичних закладів, надання рекомендацій щодо її вдосконалення. Систематизація літературних джерел та підходів до вирішення проблеми свідчить про те, що пошук нових маркетингових інструментів для інфоормування та стимулювання попиту споживачів про медичні товари та послуги (пасивний попит) в Інтернеті залишається дуже актуальною темою. Про це свідчать пошуки сучасних тенденцій використання маркетингу в медицині, всебічне вивчення маркетингових технологій управління діяльністю в системі охорони здоров'я. У той самий час контент-маркетинг розалядають як інструмент опосередкованого переконання аудиторії прийняти рішення, необхідне дистриб'ютору, вибрати його послугу. Дослідження теми дослідження ролі контент-маркетингу в просуванні медичних товарів та послуг проводять в такій логічній послідовності: опис переваг використання контент-маркетингу, важливість дотримання законодавчих вимог при рекламі та заповнення сайтів та сторінок у соціальних мережах, представлення результатів аналізу контенту вибраних клінік, розроблення пропозицій щодо вдосконалення їх контент-стратегій. Методологічний інструментарій методів дослідження включає систематизацію інформації на основі аналізу змісту оффіційних сайтів, соціальних мереж вибраних медичних установ. Об'єктом дослідження обрані медичні компанії (державні та приватні медичні центри стоматологічні клініки та медичні фармацевтичні заклади), оскільки саме вони є найбільш відвідуваними в місті, мають високий рівень конкуренції, а значить, їх має цікавити онлайн-просування послуг (особливо під час пандемії). Дослідження теоретично доводить, що контент-маркетинг є невід'ємною частиною просування медичних закладів у мережі, виявляє проблему недостатнього розуміння правильного використання цього інструменту сумськими клініками та, як наслідок, досягнення високих показників конкурентоспроможності.

Ключові слова: клініки, медичні центри, огляди, соціальні мережі, унікальна торговельна пропозиція. 